credible, but only just. But there is no reason to believe that a working star wars strategy is more easily realized. In short, and for as long as star wars remains a hypothesis to be tested, the need for arms control is as pervasive and as irresistible as President Reagan found during the first few months of his first term, in 1980.

But what is to be done about Soviet duplicity in this and other connections? At times, the US administration sounds a little like the lawyer whose defence of his client against a charge of murder takes the form of asserting that the client did not kill the victim and, then, that he did so in self-defence. The Krasnoyarsk radar is a sign (in the absence of argument to the contrary) that the Soviet Union has not been resting on its laurels, the anti-ballistic missile system around Moscow. It may also be the case that the Soviet Union is already hard at work on a research programme not very different in character from star wars itself, as the US administration claims, but that is irrelevant. The lesson that needs now to be learned is that, for as long as these schemes remain dreams (not necessarily illusions) they should not be allowed to affect policy. And if they are found feasible, their deployment will have to be discussed between the superpowers. Why not accept that now, not later?

\section{Fun made dull?}

British school mathematics may be made worse by the government's recipe for reform.

WHAT should a young person know of mathematics? And how should mathematics be taught at school? From time to time, these questions recur almost everywhere, as some mathematicians would say. Under the idiosyncratic guidance of Sir Keith Joseph, Secretary of State for Education and Science, the British government has just embarked on yet another attempt to breathe new life into a jaded curriculum. Things may seem to have changed a lot (but not for the worse) since earlier decades, when British governments behaved as if they had no right to tell the local education authorities, which administer British schools, what should be taught, but only a kind of admonitory right to complain if teaching and (more often) other aspects of school life were hopelessly awry. But on this occasion, the government has decided to stiffen its exhortation to reform by the appointment of more than 300 full-time teachers whose sole responsibility will be to ensure that the pace of reform of mathematics teaching does not flag. Those with long memories should be forgiven for reminiscing about the early 1960s, when the government encouraged renewal of the mathematics curriculum, and when local education authorities showed willing by appointing people called "advisers" to help teachers change their teaching habits.

The objective now is also much what it was two decades ago, when the general opinion was that mathematics should be made to seem more like fun to students, that it should seem more "relevant" and that teaching should concentrate more on conceptual matters than on the learning of manipulative skills. (In Britain in the 1960 s, although concepts such as that of sets made their way into the curriculum even of younger children, the "new math." never made quite the headway that terrified parents and some younger people in the United States.)

The occasion for the British government's new venture is a booklet by Her Majesty's Inspectors (of schools), called Mathematics from 7 to 16 (HMSO, £2.00), which argues much the 1960 s case for reform, but in a way that has predictably excited the British popular press. The most inflammatory passage is that which argues cogently that young people should be helped to use calculators as a means of carrying out calculations, not simply be allowed to use them for confirming the results of calculations done by other means, and which goes on to say that "long division... should no longer be generally taught" and that "logarithms, as aids to calculation, are obviously redundant". The rumble of conservative protest has been palpable, but even radicals have been taken aback.

Conservatives should not be afraid that the end of their world has come. The new document is a recipe not so much for upheaval as for consolidation, even for consolidation about modest goals. This is not surprising, since the school inspectors have themselves relied on a study of school mathematics carried out by a government committee under Dr (now Sir) William Cockcroft and published three years ago. The inspectors echo that earlier plea that the mathematics taught in schools should consist of a central core of knowledge and understanding determined by the needs, interests and abilities of most students. On this view, mathematics at school is largely a utilitarian study. Even the section in the manifesto on "conceptual structures" is largely devoted to a sensible discussion of the reasons why students should appreciate the importance of estimating the results of calculations and approximating to them (or even to the insoluble problems of the real world). The document repeatedly urges that teachers should engage their students in practical work, but it is partly redeemed by its advocacy of open-ended questions in mathematics examinations.

The more serious objection to what is now proposed is its dullness, or its potential dullness in the hands and heads of many teachers. While the language of sets may, in the 1960 s, have seemed a licence to some teachers to make algebraists of five-yearolds, the repeated exhortation to teachers now to bear in mind the practical needs of their students, especially to find jobs, will give many teachers the idea that mathematics should be turned into sophisticated mensuration. And while the inspectors' document repeats in humdrum language the belief that mathematics is more a part of modern life than of that of any previous age, it does very little to suggest to teachers that they should help their students understand how mathematics has become so powerful. Thus, absurdly, in spite of the inspectors' advocacy of computers as a means of making calculations, nothing is said about the benefits of understanding that even the simplest techniques for arithmetical manipulation (not to mention long division) involve the use of algorithms of a kind that also underlie computer programs. Fortunately, most teachers and many of their students already know better.

All is not lost, however, for the inspectors' prospectus is described as a discussion document, on which opinions will be welcome. Here are some complaints that the inspectors (and their minister) might usefully accommodate. First, because mathematics is as important as the document says, students of all ages and ability should be helped to understand how these circumstances have arisen (which argues for a little history) and why mathematics is so powerful (which argues for school-leavers knowing something of what can be accomplished by the calculus even if they have not learned to differentiate a simple function). Second, and consistently with the inspectors' utilitarian cast of mind, the curriculum should give students a general understanding of how problems of the real work are turned into problems in mathematics which, in practice, are soluble only exceptionally. Third, students need to have their spirits lifted by repeated demonstrations of the sheer neatness of much of mathematics, whence much of its power. But they need also to appreciate that, like other parts of science, mathematics remains unfinished business, as can be told at the earliest ages from the lack of an analytical formula specifying the prime numbers.

Can Sir Keith Joseph's band of advisers hope to accomplish all this? With luck, they will do much good, but there are two respects in which they will be handicapped from the outset. First, the mathematics teachers in British schools are too few and are also, too often, as unconfident of the material they hope to teach as are their students. The immediate remedy is for more in-service training, as the government agrees. The long-term solution may be unattainable, given the demand for people who can count in the economy at large. Second, a point which the government does not so far concede, there is a need for yet another deliberate attempt to redesign the mathematics curriculum by practical work by teachers working in the schools, not by edict from on high. Plainly, as things have turned out, what British school mathematics most needs is a flood of protest to the Senior Chief Inspector, Mr E. J. Bolton. 